\title{
Management of periradicular pathosis by single visit endodontic treatment using calcium hydroxide and mineral trioxide aggregate based sealer.
}

\author{
Md Abdul Hannan Sheikh ${ }^{1 *}$, Eyad Al Khalifa ${ }^{2}$, Mozammal Hossain ${ }^{3}$, Md Faruk Hossain ${ }^{4}$, Nazneen Karim ${ }^{5}$,
} S M Abdul Quader ${ }^{6}$, Fahd AA Karim ${ }^{7}$, Abdul Kader Shaikh ${ }^{8}$

\section{AFFILIATION:}

1. Classified Specialist \& Head, Dept of Conservative Dentistry \& Endodontics, Military Dental Centre Dhaka, Dhaka Cantt.

2. Colonel and Head of the Dental Department, Jaber Al Ahmed Armed Forces Hospital, Kuwait.

3. Associate Professor, Department of Conservative Dentistry and Endodontics, BSMMU. Dhaka.

4. Major, Dept of Oral \& Maxillofacial Surgery, Military Dental Centre Dhaka, Dhaka Cantt.

5. Department of Conservative Dentistry and Endodontics, BSMMU, Dhaka.

6. Associate Prof. Dept of Conservative Dentistry \& Endodontics, Update Dental College\& Hospital, Dhaka.

7. Associate Prof. Dept of Conservative Dentistry \& Endodontics, Update Dental College \& Hospital, Dhaka.

8. Associate Prof. Dept of Neurology, BSMMU, Shahbag, Dhaka.

\section{Article info.}

Received: 21 March 2020

Accepted: 13 June 2020

Volume: Vol-10, Issue-2, October 2020

DOI:

\section{https://doi.org/10.3329/updcj.v10i2.50174}

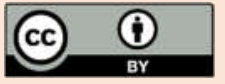

(C) Authors retain copyright and grant the journal right of first publication with the work simultaneously licensed under Creative Commons Attribution License CC - BY 4.0 that allows others to share the work with an acknowledgment of the work's authorship and initial publication in this journal.

https://creativecommons.org/licenses/by/4.0/

Publisher: Update Dental College, Dhaka, Bangladesh

Web: www.updatedentalcollege.edu.bd

E-mail: updcj@hotmail.com

\author{
* Corresponding Author \\ Lt Col Dr. Md Abdul Hannan Sheikh, \\ Classified Specialist \& Head, \\ Dept of Conservative Dentistry \& Endodontics, \\ Military Dental Centre Dhaka, Dhaka Cantt. \\ E mail-drhannan65@gmail.com \\ Mob no. +8801712202400 .
}

\section{9) Citation}

Md Abdul Hannan Sheikh, Eyad Al Khalifa, Mozammal Hossain, Md Faruk Hossain, Nazneen Karim,S M Abdul Quader, Fahd AA Karim, Abdul Kader Shaikh, Management of periradicular pathosis by single visit endodontic treatment using calcium hydroxide and mineral trioxideaggregate based sealer. UpDCJ [10(2):10-13

\section{DOI: https://doi.org/10.3329/updcj.v10i2.50174}

\begin{abstract}
:
In this study, 120 teeth having periradicular pathosis were treated with single visit root canal treatment and then obturated with either calcium hydroxide containing sealer or mineral trioxide aggregate based sealer. The healing of periradicular pathosis was examined at 3, 6, and 12 months by clinical and radiological evaluation. Collected data were analyzed with standard statistical methods by using SPSS version- 20. The results showed that at 3 and 6 months, the differences between calcium hydroxide containing sealer or mineral trioxide aggregate based sealer were not statistically significant. However, the healing capability of periapical radiolucency at 12 months between two groups was statistically significant $(P=0.03)$. The final outcome of the clinical and radiological investigation showed successful results of $96.6 \%$ and $98.1 \%$ in calcium hydroxide and mineral trioxide aggregate group, respectively. In conclusion, both calcium hydroxide and mineral trioxide aggregate based sealers are almost equally effective in single visit root canal therapy for the management of periradicular pathosis.
\end{abstract}

Key words: Periradicular pathosis, nonsurgical endodontic treatment, calcium hydroxide, mineral trioxide aggregate.

\section{INTRODUCTION:}

Infections of the dental pulp occur as a consequence of caries, dental operative procedures, and trauma, and involve a mixed, predominately Gram-negative anaerobic bacterial flora, ${ }^{1}$ and often cause total pulpal necrosis and subsequently stimulate an immune response in the periapical region. ${ }^{2}$-This is commonly referred to as a periapical lesion and appeared either in the form of dental granulomas, radicular cysts or abscess. ${ }^{2,3}$ The frequency of cysts, periapical granuloma, and abscesses were ranged between $6 \%$ to $55 \%$., $9.3 \%$ to $87.1 \%$, and $28.7 \%$ to $70.07 \%$, respectively. Furthermore, the incidence of the radicular cysts usually increases as the size of the periapical lesions increase but they may also represent as granulomas. ${ }^{3,4}$

Surgical intervention is recommended only after non-surgical techniques have failed because many studies have reported that $94.4 \%$ of complete and partial healing of periapical lesions could be achieved with nonsurgical endodontic therapy. ${ }^{5,6}$ Furthermore, it can promote the healing of large periapical lesion by cleaning, shaping, and three-dimensional fluid-tight obturation of root canal system. Root canal sealers also play an important role to attain an impermeable seal between core materials and root canal walls. They can be group according to their basic components such as zinc oxide eugenol, calcium hydroxide, glass-ionomer, resin, iodoform, silicon and recently MTA fillapex root canal sealer, and biodentine sealer... ${ }^{2,4}$

The concept of doing complete endodontic treatment in one visit is not new. It was there for at least 100 years. ${ }^{7}$ Nowadays with the development of new instruments, materials, and 
techniques single visit RCT can be done in almost all cases. It has many benefits such as less time required, economical, and more comfortable for roving and busy patients. ${ }^{8,9}$ Therefore, the purpose of this study is to compare the effectiveness of Calcium Hydroxide and MTA based sealer for managing periradicular pathosis by single visit endodontic treatment.

\section{MATERIAL AND METHODS:}

A total of 120 permanent teeth having periradicular pathosis was treated with single visit root canal treatment and then obturated either with calcium hydroxide containing sealer (Seal apex) or mineral trioxide aggregate based sealer (MTA Fillapex). The steps of the treatment procedure were as follows: mouth preparation followed by straight-line access cavity preparation and then the removal of coronal necroses tissue was performed. The root canal was then negotiated, checked the canal patency and determination of the working length. Biomechanical preparation of the canal was performed by irrigation with $2.5 \% \mathrm{NaOCl}$ and EDTA. The smear layer was further removed with liquid EDTA and $2 \%$ chlorhexidine. The canal was dry with a sterile paper point.

Root canal sealers were mixed according to the manufacturer's instructions. Mixed sealers were then applied to the root canals and its walls by using lentulo-spirals attached with a slow speed handpiece. Finally, root canals were obturated with the Gutta-percha cones and sealed by the lateral compaction technique. The access cavity was then filled with Glass-ionomer cement. Evaluation:

The healing of periradicular pathosis was examined at 3,6 , and 12 months by clinical and radiological evaluations. Collected data will be analyzed through standard statistical methods by using SPSS version- 20. Ethical clearance was obtained from the Institutional ethical board.

\section{RESULTS:}

The study involved 120 cases of endodontically involved teeth with periradicular pathosis. Out of 120 patients, 62 patients $(51.7 \%)$ were male and 58 patients $(48.3 \%)$ female, and the age range as between 10 to 40 years. The etiology of periradicular pathosis of the patients was due to caries in $54(90.0 \%)$ calcium hydroxide and 56(93.3\%) mineral trioxide aggregate. The remaining cases were due to trauma and the etiological difference between the two groups was statistically significant $(P=0.001)$.

The clinical (Table-1) and radiological findings ( Fig 1\&2) showed that after 3 months, 5(8.3\%) calcium hydroxide cases revealed no change in radiolucency, and 55(91.7) cases reduced radiolucency. On the other hand, and in MTA group, $5(8.3 \%)$ cases no change in radiolucency, $55(91.7 \%)$ cases reduced radiolucency. There was no case in both the group who showed increased and disappeared radiolucency. The Association of periapical radiolucency at 3 months between two groups was not statistically significant $(p=0.42)$.

After 6 months in $\mathrm{Ca}(\mathrm{OH}) 2$ group, $2(3.3 \%)$ cases no change in radiolucency, 58(96.7\%) cases reduced radiolucency, but none of them had increased radiolucency. In MTA group, 02(3.3\%) cases no change in radiolucency, 58(97.7\%) cases reduced radiolucency and none of them had increased radiolucency.

Table 1. Results of clinical assessment

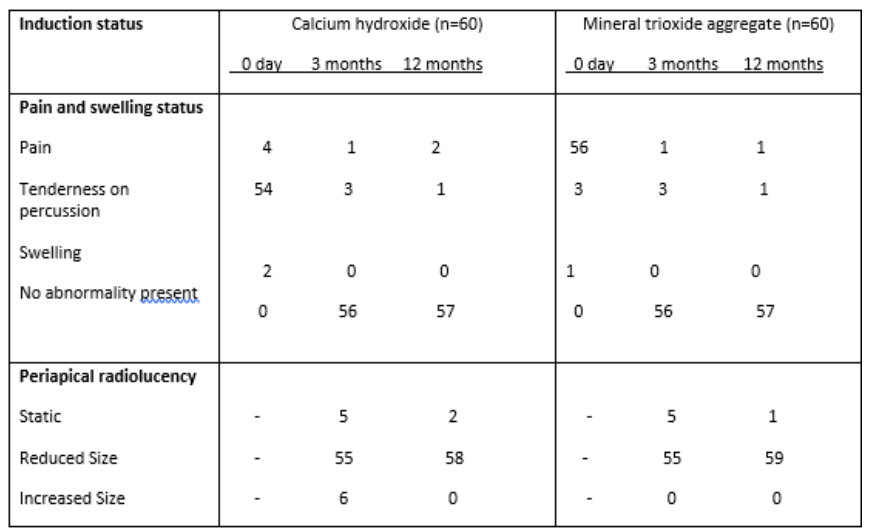

Figure 1. Representative radiological photographs of obturated tooth by mineral trioxide aggregate.

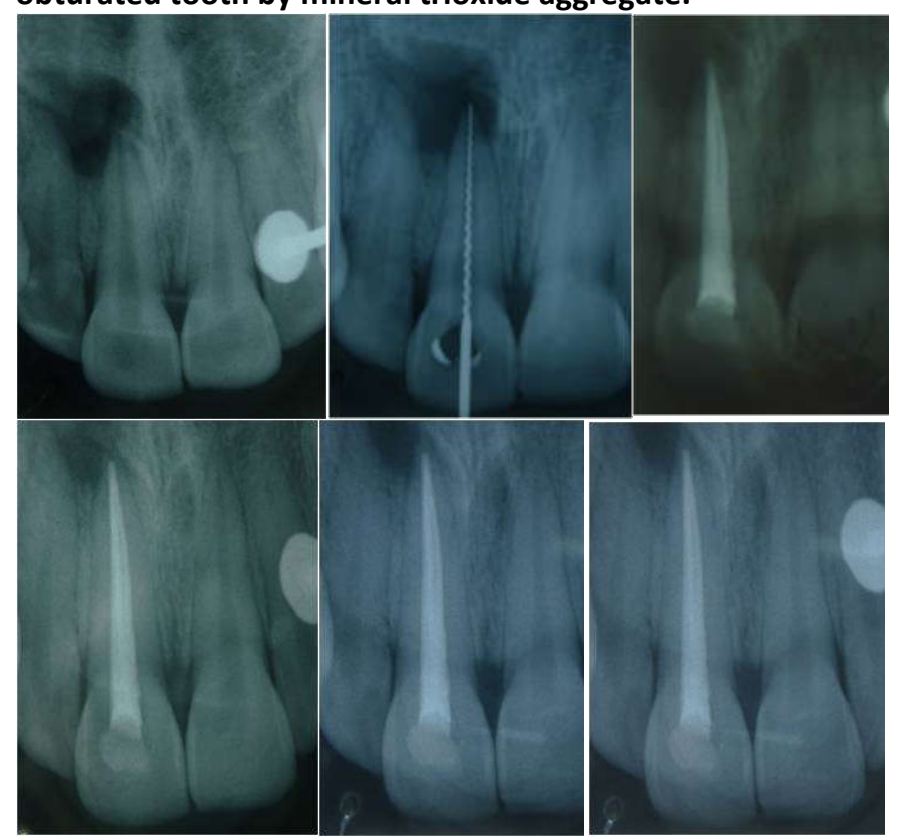

From left to right and above : Initial radiograph, Working Length Determination, Post Obturation, Follow-up (3Months), Follow-up (6Months), Follow-up (12Months)

Figure 2. Representative radiological photographs of obturated tooth by calcium hydroxide

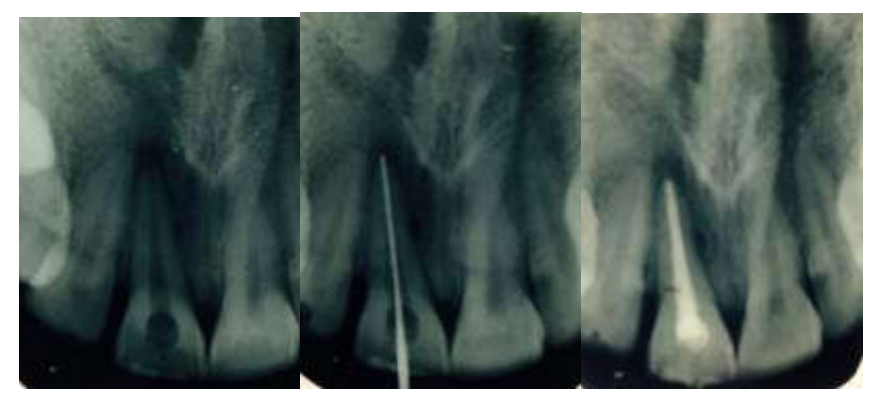




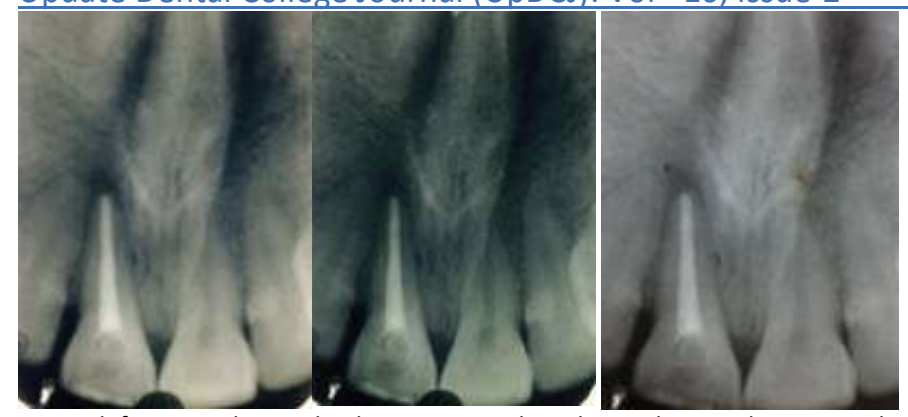

From left to right and above : Initial radiograph, Working Length Determination, Post Obturation, Follow-up (3Months), Follow-up (6Months),Follow-up (12Months)

The Association of periapical radiolucency at 6 months between two groups was statistically not significant $(p=0.07)$.

After 12 months, the radiological evaluation in $\mathrm{Ca}(\mathrm{OH}) 2$ group 02(3.3\%) cases are in static radiolucency, $58(96.67 \%)$ cases reduced radiolucency. In MTA group $01(1.7 \%)$ cases are in static radiolucency, 59 (98.3\%) cases reduced radiolucency. None of the cases had increased radiolucency. The Association of periapical radiolucency at 12 months between two groups was statistically significant $(\mathrm{P}=0.03)$.

The final outcome of the therapy with calcium hydroxide and mineral trioxide aggregate was as follows: $58(96.67 \%)$ calcium hydroxide cases were successful and $02(3.3 \%)$ were doubtful. In mineral trioxide cases, 59(98.1\%) were successful and $01(1.7 \%)$ cases were doubtful. There are no failure cases in both groups.

\section{DISCUSSION:}

The present study confirms that MTA Fillapex is also suitable for root canal obturation. Many studies have indicated that only chemico-mechanical canal preparation is not sufficient enough to disinfect the canal because it needs intra-canal medicaments like calcium hydroxide for few days to withstand the canal microorganisms. ${ }^{10,11}$ However, recently published studies described the role of instrumentation and irrigation of canal with anti-bacterial agents is more important than in dressing with the intracanal medicament in one and multiple visits. ${ }^{12,13}$ Furthermore, a hermetic 3-dimensional filling is also essential to reduce periapical inflammation. ${ }^{14}$ This filling is currently achieved using a combination of endodontic sealer and gutta-percha. Gutta-percha has good physical and biological properties, but the lack of adhesiveness and flow makes the association with endodontic sealers necessary. ${ }^{6,15}$ Moreover, a connection may be established between the main root canal and periodontal ligament, as well as the apical foramen through the root canal ramifications, such as lateral, secondary, and accessory canals. ${ }^{16,17,18}$ Therefore, to reduce the localized periodontal problems, it is also important to have the ability of root canal sealers to flow into these irregularities. ${ }^{19,20}$ The use of calcium hydroxide kept its popularity due to antibacterial activity, mediates the degradation of bacterial lipopolysaccharides. ${ }^{21}$
Furthermore, it induces healing by hard tissue formation, and control inflammatory root resorption. ${ }^{21,22}$ Sealaplex, commercial calcium hydroxide based endodontic sealer, even though relatively soluble after application but this does not affect its sealing property. ${ }^{22,23}$

Recently developed mineral trioxide aggregate initiated the closure of main canal foramen by the formation of new cementum with the absence of inflammatory cells after 6 months. ${ }^{24}$ MTA endodontic sealer (MTA fillapex, Angelus, Brazil) is composed of MTA, salicylate resin, natural resin, bismuth, and silica. In addition to its excellent biocompatibility and produces a hermetic seal, it has antimicrobial activity against $\mathrm{S}$. aureus, E. coli, C. albicans and E. faecalis due to its by its high $\mathrm{pH}$. It also provides an impermeable seal with the dentin and cementum and promotes healing of periodontal ligament. Furthermore, its sealing ability is higher than the conventional zinc oxide eugenol based cement and almost similar to epoxy resin-based cement. ${ }^{1,5,15}$ Moreover, it is less sensitive to humidity and blood contamination. ${ }^{5,25}$

By using Ca hydroxide based sealer, Oliet $\mathrm{S}^{26}$ reported a success rate of $89 \%$ for single-visit endodontic treatment; Soltanoff and Montclair ${ }^{27}$ reported a success rate of $85 \%$. Pekruhn RB ${ }^{28}$ reported a failure rate of $5.2 \%$ and a success rate of $94.8 \%$ in a study of one visit root canal treatment. Wolchs ${ }^{129}$ records of over 2000 cases treated by single visit root canal therapy showed that less than $1 \%$ of patients indicated any severe reaction. Similar type results were also observed by Grecca et al..$^{30}$ In their animal study, induction of periredicular pathosis was observed and $\mathrm{Ca}(\mathrm{OH}) 2$ containing sealer (Sealapex) showed a better result than the Zinc oxide-eugenol sealer $(P<0.05)$

According to a study by Filho MT et al $^{31}$ it was found that $\mathrm{Ca}(\mathrm{OH}) 2$ containing sealer (Sealapex) was significantly better in terms of histopathological repair when compared with the ZOE sealer of the Grossman type. In cases of overfilling, Filho MT et al ${ }^{31}$ found in a histopathological evaluation that ZOE in contact with periapical tissues promoted a severe inflammatory infiltrate. edema, congested capillaries, and scarce collagen fibers. In contrast, when Sealapex was extruded into the periapical region, there was the intense activity of macrophages and the formation of mineralized areas close to the sealer. So inflammatory infiltrates in the periapical tissues were mild in the $\mathrm{Ca}(\mathrm{OH}) 2$ (Sealapex) Group (57.9\%) when compared to the ZOE group (92.9\%).

\section{CONCLUSION:}

It is well accepted that after complete debridement and disinfection, total obliteration of the root canal system performed with biocompatible materials constitutes one of the principal prerequisites for successful endodontic therapy. For attaining this object, the choice of a sealer will influence the outcome of endodontic therapy. Mineral trioxide aggregate and calcium hydroxide could be used as root canal sealer with high biocompatibility compared with other sealers. 


\section{REFERENCES:}

1. Sundqvist G. Taxonomy, ecology and pathogenicity of the root canal flora. J Oral Surg Oral Med Oral Pathol. 1994;78: 522-30. https://doi.org/10.1016/0030-4220(94)90047-7

2. ydney GB, Ferreira M, Deonizio MDA, Leonardi DP, Batista A. Análise do perfil de escoamento de seiscimentos endodônticos. RGO. 2009; $57: 7$ 11.

3. Torabinejad, M. and Walton, R.E. Periradicular lesion. In: J.I. Ingle and L.K. Blackland, ed. Endodontics. 5th ed. Hamilton Ontario, Canada : B.C. Decker, 2002; 175-201.

4. Bhaskar, S.N. Periapical lesion- Types, incidence and clinical features. $J$ Oral Surg Oral Med Oral Pathol. 1996; 21: 657-70. https://doi.org/10.1016/0030-4220(66)90044-2

5. Bogen G, Kuttler S. Mineral trioxide aggregate obturation: A review and case series. J Endod 2009; 35: 777-90. https://doi.org/10.1016/i.joen.2009.03.006 PMid:19482173

6. Camps J, Pommel L, Bukiet F, About I. Influence of the powder/liquid ratio on the properties of zinc oxide-eugenol-based root canal sealers. Dent Mater. 2004; 20:915-23. https://doi.org/10.1016/i.dental.2004.02.002 PMid:15501319

7. Nandakishore KJ, Shija AS, Vinaychandra R. Single visit endodontics : A review. J Health Sc Res. 2011; 2: 23-28.

8. Pekruhn RB. Single visit Endodontic therapy: A preliminary clinical study. J Am Dent Assoc. 1981; 103:875-77. https://doi.org/10.14219/iada.archive.1981.0400 PMid:6947006

9. Jurcak JJ, Bellizzi R, Loushine RJ. Successful single visit Endodontics during operation Desert Shield. J Endod. 1993; 19: 412-13. https://doi.org/10.1016/S0099-2399(06)81507-4

10. Sjogren U, Figdor D, Persson S, Sundqvist G. Influence of infection at the time of root filling on the outcome of endodontic treatment of teeth with apical periodontitis. Int Endod J. 1997; 30: 297-306. https://doi.org/10.1111/j.1365-2591.1997.tb00714.x https://doi.org/10.1046/j.1365-2591.1997.00092.x PMid:9477818

11. Ghoddusi J, Javidi M, Zarrabi MH, Bagheri H. Flare-ups incidence and severity after using calcium hydroxide as intracanal dressing. NY State Dent J. 2006; 72: 24-28.

12. Schirrmeister JF Leibenow AL, Braun G, Witer A, Hellwig E, Al-Ahmad A. Detection and eradication of microoganisms in root-filled teeth associated with periradicular lessions: An in-vivo study. J Endod. 2007:33:536-40.

https://doi.org/10.1016/j.joen.2007.01.012 PMid:17437867

13. Walton R, Fauad A. Endodontic inter-appointment flare-ups: A prospective study of incidence and related factors. J Endod. 1992; 18: 172-77. https://doi.org/10.1016/S0099-2399(06)81413-5

14. De Almeida WA, Leonardo MR, Tanomaru Filho M, Silva LA. Evaluation of apical sealing of three endodontic sealers. Int Endod J. 2000; 33:25-27. https://doi.org/10.1046/j.1365-2591.2000.00247.x PMid:11307470

15. Duarte $M A H$, Ordinola-Zapata $R$, Bernardes RA, Bramante $C M$, Bernardineli N, Garcia RB et al. Influence of calcium hydroxide association on the physical properties of AH Plus. J Endod 2010;36: 104850 .

https://doi.org/10.1016/j.joen.2010.02.007 PMid:20478463

16. Gomes-Filho JE, Watanabe S, Bernabé PF, de Moraes Costa MT. A mineral trioxide aggregate sealer stimulated mineralization. J Endod. 2009; $35: 256-60$ https://doi.org/10.1016/j.joen.2008.11.006 PMid:19166785
17. Holland R, de Souza V, Nery MJ, OtoboniFilho JA, Bernabé PF, Dezan E., Júnior. Reaction of dogs' teeth to root canal filling with mineral trioxide aggregate or a glass ionomer sealer. J Endod. 1999; 25:728-30. https://doi.org/10.1016/S0099-2399(99)80118-6

18. Hoshino, E., Kurihara, N.A., Satol, U.H., Sato, M., Kotak, et.al. In vitro antibacterial susceptibility of bacteria taken from infected root dentine to a mixture of Ciprofloxacin, Metronidazole, Minoclicin in situ. Int Endod J. 1996; 29: 125-130. https://doi.org/10.1111/j.1365-2591.1996.tb01173.x PMid:9206436

19. Lee SJ, Monsef M, Torabinejad M. Sealing ability of a mineral trioxide aggregate for repair of lateral root perforations. J Endod. 1999; 19: 54144. https://doi.org/10.1016/S0099-2399(06)81282-3

20. Mickel AK, Wright ER.Growth inhibition of Streptococcus anginosus (milleri) by three calcium hydroxide sealers and one zinc oxide-eugenol sealer. J Endod. 1999; 25: 34-37. https://doi.org/10.1016/S0099-2399(99)80396-3

21. Harmann BW. Dentinobliteration der Wuzrelkanale Nach der Behandlung Mit Calcium. Zahnaerztl Rund 1930; 888-89.

22. Tronstad L, Barnett F, Flax M. Solubility and biocompatibility of calcium hydroxide containing root canal sealers. Endod Dent Traumatol. 1988; 4; 152-159.

https://doi.org/10.1111/j.1600-9657.1988.tb00314.x PMid:3267525

23. Leonardo MR, Salgado AAM Da Silva LAB, Filho MT. Apical and periapical repair of dog's teeth with periapical lesions after endodontic treatment with different root canal sealers. Pe Squi Odontol Bras. 2003; 17: 69-74. https://doi.org/10.1590/\$1517-74912003000100013 PMid:12908063

24. Holland R, de Souza V, Nery MJ, Otobonifilho JA, Bernabé PF, Dezan E., Júnior. Reaction of dogs' teeth to root canal filling with mineral trioxide aggregate or a glass ionomer sealer. J Endod 1999; 25:728-30. https://doi.org/10.1016/S0099-2399(99)80118-6

25. Moraes SH, Zytkievitz E, Ribeiro JC, Heck AR, Aragão EM. Cimentosendodônticos: tempo de presa e escoamento de doiscimentosobturadores de canaisradiculares. RGO 1989; 37: 455-59.

26. Oliet S. Single visit Endodontics: A clinical study. J Endod. 1983; 9: 14752. https://doi.org/10.1016/S0099-2399(83)80036-3

27. Soltanoff W, Montclair NJ. A comparative study of the single visit and the multiple visit endodontic procedure. J Endod. 1978; 4 :278-81. https://doi.org/10.1016/S0099-2399(78)80144-7

28. Pekruhn RB. Single visit endodontic therapy: A preliminary clinical study. J Am Dent Assoc. 1981; 103: 875-77. https://doi.org/10.14219/jada.archive.1981.0400 PMid:6947006

29. Wolch I. One appointment endodontic treatment. Journal of Canadian dental association 1975; 41: 613-15.

30. Grecca FS, Leonardo MR, Da Silva LAB Filho MT, Borges MAG. Radiographic evaluation of periradicular repair after endodontic treatment of dog's teeth with induced periradicular periodontits. J Endod. 2001; 27: 610-12 https://doi.org/10.1097/00004770-200110000-00002 PMid:11592488

31. Filho MT, Leonardo MR, Silva LAB, Utrilla LS. Effect of different root canal sealers on periapical repair of tooth with chronic periradicular periodontitis. Int Endod J. 1998; 31: 85-89. https://doi.org/10.1046/j.1365-2591.1998.00134.x PMid:9868933 